\title{
ATIVIDADES HIDROLIÍTICAS DE AMOSTRAS DE CONTEÚDO DO INTESTINO DELGADO DE BOVINOS ADULTOS, INFECTADOS OU NÃO por Eurytrema sp, DETERMINADAS POR DIFUSÃO RADIAL ENZIMÁTICA
}

\author{
HYDROLYTIC ACTIVITIES OF SMALL INTESTINE CONTENT AS DETERMINED BY \\ RADIAL ENZYME DIFFUSION IN Eurytrema sp INFECTED \\ OR NON INFECTED CATTLE
}

Pacífico Antônio Diniz Belém ${ }^{1}$ Carlos Batista de Assis ${ }^{2}$ Marcelo Lopes de Santana $^{3}$

\begin{abstract}
Empregando-se difusão radial enzimática em ágar gel, atividades hidrolíticas de amostras de conteúdo do intestino delgado de 38 bovinos adultos de matadouro foram mensuradas em animais agrupados como possuidores de pâncreas hígidos (controle) e parasitados por Eurytrema sp, estes, segundo dois graus de infecção reconhecidos. Para tal, foram empregados quatro substratos, dos quais caseinato de cálcio e óleo de milho tiveram de ser desconsiderados porque, no caso deles, não houve formação de halos ou estes apresentaram limites imprecisos. Apesar desses problemas não terem ocorrido quando o substrato era leite em pó desnatado ou amido, as atividades hidrolíticas encontradas foram equivalentes, independentemente da condição de parasitismo e grau de infecção verificados $(P>0,05)$. Concluiu-se, então, que a técnica de difusão radial enzimática, pelo menos com os substratos empregados, foi incapaz de acusar disfunções pancreáticas exócrinas em bovinos infectados por Eurytrema sp.
\end{abstract}

Palavras-chave: Eurytrema, função pancreática, bovinos.

\section{SUMMARY}

Hidrolitic activities of small intestine content as determined by radial enzyme diffusion in agar gel containing calcium caseinate, corn oil, starch or skimmed milk were measured in 38 mature cattle from slaughterhouse. Each one were identified as normal or infected and then classified into two different grades according to pancreatic ducts lesions and parasite burden. The substrates calcium caseinate and corn oil did not shown cleared zones in several radial enzyme diffusion tests or it was difficult to get a correct measure of the diameters. Such problems, however, were not observed with starch and skimmed milk. In these cases, hidrolitic activities were similar in both control and Eurytrema sp infected groups, despite of the pancreatic duct lesions and parasite load (P>0.05). So, it was concluded that the radial enzyme diffusion method couldn't shown any exocrine pancreatic disfunction in Eurytrema sp infected cattle.

Key words: Eurytrema, pancreatic function, fecal hydrolases, cattle.

Na euritrematose bovina ocorre obstrução de ductos e pancreatite crônica (BURGGRAAF, 1935; FREITAS, 1976; WHITLOCK \& DEEM, 1981; BELÉM et al., 1994), além de comprometimento da função endócrina quando as lesões são mais extensas (BELÉM et al., 1986 e 1997). Entretanto, na maioria das vezes, ela é subclínica ou exibe sinais inespecíficos, fato que desperta o interesse em desenvolver provas de função pancreática exócrina que possam auxiliar no diagnóstico de disfunções. Dessas, apenas a determinação da amilosúria (CODO, 1953) e a prova do filme (BELÉM $\boldsymbol{e t}$ al., 1992) foram ensaiadas, mas se mostraram inadequadas. Por outro lado, existem outras, recomendadas para cães e gatos, que, talvez, pudessem servir a

\footnotetext{
${ }^{1}$ Médico Veterinário, Doutor em Clínica: Fisiopatologia Médica, Professor Titular do Departamento de Veterinária (DVT), Universidade Federal de Viçosa (UFV), 36571-000, Viçosa, MG. Bolsista do CNPq. E-mail: pbelem@mail.ufv.br.

${ }^{2}$ Médico Veterinário, Doutor em Clínica: Fisiopatologia Médica, Professor Adjunto, DVT, UFV.

${ }^{3}$ Médico Veterinário, Bolsista de Aperfeiçoamento do CNPq, DVT, UFV.
} 
esses propósitos. Dentre elas, destaca-se a avaliação de atividades hidrolíticas das fezes ou conteúdo intestinal por difusão radial enzimática em ágar gel (WESTERMARCK \& SANDHOLM, 1980).

À medida que a euritrematose bovina se faz acompanhar de diminuição ou ausência de tripsina e amilase no suco pancreático (BURGGRAAF, 1935), esta pesquisa procurou avaliar atividades hidrolíticas de amostras de conteúdo do intestino delgado de bovinos, infectados ou não por Eurytre$\boldsymbol{m a} \mathbf{s p}$, através de difusão radial enzimática em ágar gel. Se essa prova permitisse reconhecer disfunções pancreáticas exócrinas ocasionadas pela referida parasitose, posteriormente, proceder-se-ia a ajustes que permitissem mensurar atividades hidrolíticas em amostras fecais.

O material foi obtido aleatoriamente de 38 bovinos adultos, machos e fêmeas, criados a pasto em Viçosa e cidades vizinhas, todos abatidos para consumo durante os meses de maio e junho de 1998. Após evisceração de cada animal, o pâncreas e um segmento do intestino delgado, compreendido entre o piloro e o íleo, eram recolhidos, identificados e processados conforme se segue:

1. pâncreas: esses eram examinados à procura de espécimes de Eurytrema sp e, para isso, o ducto pancreático acessório e os ductos tributários eram submetidos à abertura longitudinal. No caso de serem encontrados os trematódeos pesquisados e antes deles serem removidos, cada pâncreas era classificado confome o grau de infecção presente em 1+ ou $2+$, tomando-se como referencial a aglomeração dos parasitas e a intensidade de dilatação dos ductos visualizadas. Assim, grau 1+ correspondia àquelas situações nas quais os parasitas albergados se faziam presentes apenas no interior do ducto pancreático acessório sem, contudo, adentrarem-se nos tributários e, via de regra, achavam-se em número que lhes permitia serem contados com relativa facilidade. Ademais, alterações macroscópicas da mucosa dos ductos e espessamento das paredes não se faziam presentes ou eram discretas. $\mathrm{O}$ grau $2+$, no entanto, era caracterizado pela presença maciça de parasitas na maioria ou em todos os ductos tributários e ao longo do ducto pancreático acessório. Estes, nessas condições, apresentavam-se com nítido espessamento da mucosa, presença de muco no seu interior e evidente dilatação que, muitas vezes, conferia-lhes saliência na superfície dos pâncreas correspondentes;

2. intestino delgado: uma alíquota do conteúdo era submetida à técnica de difusão radial enzimática em ágar gel contendo amido, óleo de milho e caseinato de cálcio como substrato, conforme WESTERMARCK \& SANDHOLM (1980). Adicionalmente, placas contendo leite em pó desnatado como substrato, preparadas seguindo-se os mesmos procedimentos recomendados para de caseinato de cálcio, foram também utilizadas.

Os testes foram feitos em duplicata e os diâmetros dos halos formados nas placas medidos com auxílio de um paquímetro. Os resultados obtidos para cada substrato, em bovinos parasitados por Eurytrema sp, segundo o grau de infecção constatado, e naqueles possuidores de pâncreas hígidos (controle), foram tabulados e submetidos à análise de variância para experimentos inteiramente casualizados (SNEDECOR \& COCHRAN, 1985).

A técnica de difusão radial enzimática em ágar gel contendo os substratos caseinato de cálcio e óleo de milho, recomendada, respectivamente, para avaliar as atividades proteolítica e lipolítica contidas em fezes e conteúdo do intestino delgado de cães (WESTERMARCK \& SANDHOLM, 1980), não pode ser considerada para bovinos, independentemente deles serem ou não parasitados por Eurytrema sp. No primeiro caso, o caseinato de cálcio mostrou-se pouco solúvel e isso prejudicou a leitura, pois formavam-se halos pouco nítidos. Entretanto, em todos os casos que as mensurações puderam ser efetuadas com segurança (cerca de $60 \%$ das vezes), foi possível constatar que os diâmetros dos referidos halos eram praticamente os mesmos encontrados nas placas contendo leite em pó desnatado. Já o emprego do óleo de milho, conforme referido, não permitiu, sequer, formação de qualquer tipo de halo em 16 amostras examinadas (nove procedentes de animais parasitados e sete de não parasitados).

A tabela 1 apresenta os diâmetros médios dos halos formados em ágar gel contendo amido e leite em pó desnatado como substratos para determi-

Tabela 1 - Médias e desvios-padrões dos diâmetros ( $\mathrm{mm})$ dos halos obtidos na prova de difusão radial enzimática em ágar gel contendo leite em pó desnatado ou amido como substrato para avaliação das atividades hidrolíticas de amostras de conteúdo do intestino delgado de bovinos adultos infectados ou não por Eurytrema, segundo o grau de infecção presente (G1+ e G2+)

\begin{tabular}{cccc} 
Grupos de Bovinos & $\mathrm{n}$ & \multicolumn{2}{c}{ Substrato $^{(1)}$} \\
\cline { 3 - 4 } & & Leite em Pó Desnatado $^{(2)}$ & Amido $^{(3)}$ \\
& \multicolumn{3}{c}{} \\
\hline Não Infectados & 16 & $1,594 \pm 0,371 \mathrm{a}$ & $1,581 \pm 0,223 \mathrm{~b}$ \\
Infectados G1+ & 9 & $1,611 \pm 0,314 \mathrm{a}$ & $1,617 \pm 0,245 \mathrm{~b}$ \\
Infectados G2+ & 13 & $1,713 \pm 0,267 \mathrm{a}$ & $1,765 \pm 0,256 \mathrm{~b}$
\end{tabular}

\footnotetext{
(1) Em cada coluna, médias seguidas de uma mesma letra não diferem entre si $(\mathrm{P}>0,05)$.

${ }^{(2)} \mathrm{s}=0,3256 \mathrm{~mm}$ e $\mathrm{CV}=19,8 \%$

(3) $\mathrm{s}=0,2325 \mathrm{~mm}$ e $\mathrm{CV}=14,1 \%$.
} 
nação das atividades hidrolíticas dos conteúdos do intestino delgado, segundo a condição de parasitismo e o grau de infecção presentes. Como se vê, não foi possível assinalar diferenças quaisquer, independente de o substrato ter sido leite em pó desnatado ou amido. Os graus de lesão pancreática constatados também não interferiram no comportamento dos animais diante dos testes de difusão radial enzimática, aos quais seus conteúdos intestinais foram submetidos $(\mathrm{P}>0,05)$.

Conclui-se, portanto, que a difusão radial enzimática, tal como proposta para fins diagnósticos no cão, não é apropriada quando se trata de bovinos infectados por Eurytrema. Contudo, se entendido que aperfeiçoamentos da referida prova devam ser buscados, mesmo em outras espécies, a substituição do caseinato de cálcio por leite em pó desnatado simplifica bastante o preparo das placas, tem a vantagem de permitir uma melhor visualização do halo formado e não difere do que seria observado utilizando-se o caseinato de cálcio. É óbvio, no entanto, que neste caso estariam sendo avaliadas atividades amilolítica e proteolítica conjuntamente.

\section{REFERÊNCIAS BIBLIOGRÁFICAS}

BELÉM, P.A.D., ALVES, L.R.V., SANTANA, M.L. Associação entre parasitismo por Eurytrema sp e glicemia, em bovinos. Rev Vet Zoot, v.9, p.49-54, 1997.
BELÉM, P.A.D., OLIVEIRA, M.R., PADOVANI, C.R., $\boldsymbol{e} \boldsymbol{t}$ al. Alterações pancreáticas em bovinos naturalmente infectados por Eurytrema sp e sua associação com a carga parasitária e o número de ovos por grama de fezes (OPG). Bras J Vet Res Anim Sci, v.31, p.273-281, 1994.

BELÉM, P.A.D., OLIVEIRA, M. R., PADOVANI, C. R. Reavaliação da prova do filme como método de diagnóstico presuntivo de infecção por Eurytrema $\mathbf{s p}$ em bovinos. Braz J Vet Res Anim Sci, v.29, p.181-184, 1992.

BELÉM, P.A.D., SILVA, J.C.P., VIEIRA, D. Diabete mellitus em bovino. In: ENCONTRO DE PESQUISAS VETERINÁRIAS VETERINÁRIAS, 11, 1986, Jaboticabal, SP. Resumos... Jaboticabal : Faculdade de Ciências Agrárias e Veterinárias, UNESP, 1986. p.62.

BURGgRAAF, H. Pancreas - distomatose. T Diergeneesk, v.62, p.399-407, 479-481, 1935.

CODO, V. Dosagem da amilosúria em bovinos parasitados pelo Eurytrema coelomaticum. R Ceres, v.9, p.202-209, 1953.

FREITAS, M.G. Helmintologia veterinária. Belo Horizonte : Rabelo \& Brasil, 1976. 369p.

SNEDECOR, G.M., COCHRAN, W.G. Statistical methods. Ames : ISU, 1985. 580p.

WESTERMARCK, E., SANDHOLM, M. Faecal hydrolase activity as determined by radial enzyme diffusion: a new method for detecting pancreatic dysfunction in the dog. Res Vet Sci, v.28, p.341-349, 1980.

WHITLOCK, R.H., DEEM, D.A. Pancreatitis: pancreatic parasites. In: HOWARD, J.L. Current veterinary therapy. Food animal practice. 3 ed. Philadelphia : Saunders, 1981. p.918.

Ciência Rural, v. 30, n. 2, 2000. 